Indonesian Science Education Research

(ISER)

Available online https://jurnal.unimed.ac.id/2012/index.php/iser

ISSN Online: 2715-4653

\title{
ANALYSIS OF IMPLEMENTATION OF TPACK BY TEACHERS THROUGH DISTANCE LEARNING AT JUNIOR HIGH SCHOOL IN MEDAN
}

Sihombing R A, Manurung G A, Simanjuntak L A,

Department of Science Education Universitas Negeri Medan

rizkyagassy@mhs.unimed.ac.id

Accepted: October $9^{\text {th }}, 2021$. Published: December $31^{\text {th }}, 2021$

\begin{abstract}
This research aims to analyze the application of the TPACK framework by teachers in distance learning at junior high schools in Medan. In this research also used a qualitative descriptive method by providing a google form questionnaire to 10 junior high school teachers in the city of Medan. The data was obtained based on the answers to questions from 10 junior high school science teachers, where 7 teachers were public school educators and the other 3 teachers were educators in private schools from different schools. The process of collecting data through a questionnaire containing questions that must be filled in by the teacher about their agreement or disagreement with the questions given in the questionnaire (Likert scale). The questions made are invincible with the TPACK aspect. Based on the instruments that have been developed, researchers have obtained that the teachers already know and apply TPACK in distance learning well through the understanding and abilities possessed by the junior high school science teachers in carrying out the learning process in the classroom, especially on the topic of temperature and heat.
\end{abstract}

Keywords: TPACK framework, science teacher, distance learning, junior high school. 


\section{Introduction}

Based on the government's decision on March 24, 2020, the Ministry of Education and Culture issued circular letter number 4 of 2020 concerning the implementation of education policies in the emergency period of the spread of Covid-19. The letter describes the learning process carried out online/ remotely in their respective homes to provide new and meaningful learning experiences for educators, students and parents. Online learning is a reality that must be faced along with the development of science and technology/communication technology. The number of online learning platforms that can be applied these days, changes habits in the world of education. Online learning is a learning system that is carried out not face to face, but using a platform that can help the teaching and learning process that is carried out even though it is a long distance. The purpose of online learning is to provide quality learning services in a network that is massive and open to reach more and wider study space enthusiasts (Sofyana \& Abdul, 2019, p. 82).

Online distance learning is carried out to avoid the spread of the COVID-19 virus with school clusters. Therefore, the learning atmosphere changes and must immediately adapt to new habits, namely students learning from home. So blended learning is applied by combining synchronous and asynchronous learning. Synchronous or virtual face-to-face using Web Conferences from various platforms, which are combined with asynchronous learning or outside learning hours that have been scheduled by the school. Asynchronous activities can be in the form of students studying the learning material that has been packaged by the teacher in the Learning Management System (LMS) in the form of teaching materials in the format of pdf, powerpoint, Student Worksheets or video scribe which can be used to support discussion taught.

Implementation of distance learning activities teachers and students face various challenges in its implementation. "Teaching with technology is not a one-size-fits-all approach because it depends on the type of technology at the time it is used and also on the content of the curriculum being taught" (Orlando \& Attard, 2015, p. 119). This means, the use of technology raises another additional factor in the pedagogy of teaching and the process of building learning experiences (Swan, 2017, p. 21). Likewise with PJJ during a pandemic where the strategy of implementing online-based learning also caused various kinds of problems, both from students and teachers.

The creativity of educators is very influential in achieving online learning goals. The obstacle faced is that teachers have to innovate so as to create pleasant learning conditions for students by utilizing existing technology. As professional educators, teachers must be able to collaborate on a variety of learning methods. Teachers are expected to be able to act as mentors or remote tutors as well as facilitators for students. This can be achieved if an educator is able to innovate in online learning by taking advantage of technological advances. But in reality in the field, there are still teachers who cannot operate technology so that it affects the learning objectives not being achieved online. This is due to the lack of counseling and training for educators about technology in the learning system.

Based on Shulman's ideas about PCK, Mishra \& Koehler (2006) have added technology to PCK, with the term TPACK (technological pedagogical and content knowledge). According to Mishra \& Koehler (2006), TPACK is a framework that tries to understand the relationship between pedagogical knowledge, content knowledge, and the use of technology (technological knowledge). In TPACK, the teacher's knowledge to integrate technology in learning makes learning effective and efficient. Technology integration is considered a closely related teaching component and is included in PCK (Oyanagi \& Satake, 2016).

Natural Science Education is a term related to how to find out about nature systematically, this is intended so that students not only master a collection of knowledge in the form of facts, concepts or principles, but also a process of discovering Natural Science (IPA) to function to provide knowledge about various types of natural and artificial environments in relation to everyday life, which are concrete and can be proven mathematically by using formulas in equations in the teaching and learning process in schools. The science concept contains 
concepts from three disciplines, namely Physics, Chemistry, and Biology. Temperature and heat are physical materials. This material has been obtained by students from the elementary school level (Witanecahya, 2014). Natural Science is a science that equips students with knowledge, understanding, and abilities, therefore science learning needs strategies to determine student learning success because students are not only required to master knowledge but also skills. It is not uncommon to find in the learning process the role of students only as listeners and teachers only to convey information, therefore a learning strategy using appropriate methods so that students' learning skills and success can achieved (Rossicca, et al, 2019).

Farikhah's research (in Yulida, 2014), about Technological Pedagogical Content Knowledge (TPACK): says that TPACK is a knowledge framework for learning writing skills. lecturers in the learning process of writing (writing) in the classroom. Similarity, this study has similarities in the importance of integrating the skills of content knowledge, pedagogy, and technology integration in the learning process. The difference, this study focuses on integrating TPACK in lecturers, learning to write in class, and the author focuses on integrating the application of TPACK in junior high school teachers and in distance learning on temperature and heat material. The novelty of this research that is not found in previous research is the integration of the actualized application of Technological Pedagogical and Content Knowledge (TPACK) in distance learning about temperature and heat material.

Integrating both technology, pedagogy and teaching materials is an important thing to apply. This is closely related to the Technological, Pedagogical, Content, Knowledge TPACK framework (Koehler, Mishra, \& Cain, 2013). TPACK integration helps in the implementation of online learning (Kohler, et al, 2013). According to Pinkley (2010) adding in global life where technology has become an integral part of everyday life, more and more people use technology both for personal needs and needs in the professional world. However, teachers in implementing online learning tend to carry out online learning through applications. Teachers have not integrated pedagogy and teaching materials. This was conveyed by Drajati (2020) that teachers have not integrated
TPACK in online learning. So that students have not actively involved in learning and students tend to feel bored and seem to ignore the teaching material provided by the teacher.

Based on the description above, the main objective in this study is to analyze the application of the TPACK framework by teachers in distance learning at junior high schools in Medan.

\section{Research Method}

The research method used by the writer in this research is descriptive qualitative method. The methodology itself is a process, principles, and procedures that we use to approach problems and seek answers (Mulyana, 2008: 145). Another meaning of methodology according to Arina (2018), methodology is a formula in the application of research where in carrying out the research there are steps and also the results of the research. While the research methodology is a method or technique that is arranged regularly used by a researcher to collect data and information in conducting research that is tailored to the subject and object under study.

According to Arikunto's (2010) opinion, descriptive research is not intended to test certain hypotheses, but only describes what it is about a variable. According to Arikunto (2010) the qualitative research method is a display in the form of spoken or written words that are observed by researchers, and objects that are observed in detail so that the implied meaning in the document or object can be captured. So it can be concluded that qualitative descriptive research in this study is to see, review and describe in numbers about the object under study as it is and draw conclusions about it according to the phenomena that appear at the time the research was carried out.

The data collection technique was carried out through the technique of giving a modified google form questionnaire from a Denise journal questionnaire (2009) to several junior high school teachers in the city of Medan. Data is needed to complete the focus of this research in describing and analyzing various problems faced by teachers regarding the application of the TPACK framework during distance learning in several junior high schools in Medan. In addition, this study also describes the framework of the TPACK that is applied by the teacher so that the distance learning process continues to run effectively. 


\section{Result and Discussion}

Result

The results of the analysis of the TPACK questionnaire data by several junior high school teachers in Medan are presented in the following tables.

The instrument used in this study was a closed questionnaire contains statements that must be filled in by the teacher about their agreement or disagreement with the questions given in the questionnaire (Likert scale). The questions that have been made are adjusted to the TPACK aspects (adapted by Suryawati, et al, 2014; Tian, et al. 2012; Chai, Koh, Tsai, \& Tan, 2011; Schmidt, et al, 2009) which includes Technology Knowledge (TK), Content Knowledge (CK), Pedagogical Knowledge (PK), Technological Content Knowledge (TCK), Pedagogical Content Knowledge (PCK), Technological Pedagogical Knowledge (TPK), and Technological Pedagogical and Content Knowledge (TPACK). The questionnaire on TPACK that was developed consists of 28 questions that must be filled in by the respondent.
The data is obtained based on the answers to questions from 10 junior high school science teachers, where 7 teachers are public school educators and the other 3 teachers are educators in private schools from different schools. Of the 10 teachers, it is known that 8 teachers have teaching experience over 5 years and the other 2 teachers have teaching experience for 1-5 years. The answers are obtained based on answers to questions via the google online form. The results of the google form show that:

\section{Technology Knowledge (TK)}

Technology Knowledge refers to knowledge of various technologies from lowtechnology to digital technology that can be integrated into curriculum and learning and refers to skills in using it (Schimdt, 2009; Kohler et al, 2014; De Rossi \& Trevisan, 2018). The results of the Technology Knowledge questionnaire data analysis can be seen in Table 1 below:

Table 1. Questionnaire results for aspects of Technology Knowledge (TK)

\begin{tabular}{|c|c|c|c|c|c|c|}
\hline No & Question & Never & Rarely & Sometimes & Often & Always \\
\hline 1. & $\begin{array}{l}\text { I know how to solve technical problems } \\
\text { that occur }\end{array}$ & & & $1(10 \%)$ & $2(20 \%)$ & $7(70 \%)$ \\
\hline 2. & I can learn technology easily & & & & $6(60 \%)$ & $4(40 \%)$ \\
\hline 3. & $\begin{array}{l}\text { I follow important new technological } \\
\text { developments }\end{array}$ & & & & $2(20 \%)$ & $8(80 \%)$ \\
\hline 4. & $\begin{array}{l}\text { I often and excited to try the latest } \\
\text { development technology }\end{array}$ & & & & $2(20 \%)$ & $8(80 \%)$ \\
\hline 5. & $\begin{array}{l}\text { I have technical skills that I can use with } \\
\text { the help of technology }\end{array}$ & & & & $4(40 \%)$ & $6(60 \%)$ \\
\hline
\end{tabular}

Based on the data table 1 , the results of the questionnaire for the Technology Knowledge (TK) aspects can be explained and concluded that:

- For the first question about the teacher knowing how to solve technical problems that occur. Based on the answers from 10 teachers, there were 7 teachers who answered always, 2 teachers answered often, and 1 teacher answered sometimes. From this data, the average teacher knows how to solve technical problems that occur in the classroom.

- The second question about teachers being able to learn technology easily, was found that 4 teachers answered always, 6 teachers answered often. This shows average teacher often studies technology, can learn it easily.
- In the third question about teachers following important new technology developments, the results showed that 8 teachers answered always, 2 teachers answered often. This shows that the average teacher is always up to date with important new technology developments.

- The fourth question is about the teacher often and likes to try the latest development technology, so the result is that 8 teachers answer always, 2 teachers answer often. This shows that the average teacher often likes to try the latest technology developments.

- The fifth question regarding teachers have technical skills that they can use with the help of technology, then the result is that 6 teachers answered always, 4 teachers answered often. This shows that on average teachers have 
technical skills that they can use with the help of technology.

So it can be concluded that some junior high school teachers in the city of Medan are in the good category in the aspect of Technology Knowledge. This means that the ability of teachers in the field of technology, both knowledge and skills, is good. This is in line with the results of Hardinata A's research (2020) on how teachers use technology in online learning during the pandemic. teachers try to combine several online learning platforms and social media to make learning more meaningful.

This data is in line with a survey conducted by the association of Indonesian internet service providers (APJII, 2016) which that internet users in Indonesia in 2016 were 132.7 million people $(50 \%$ of the total population) with 22.3 million users aged between 20-24 years of age and the internet

content most accessed by internet users is social media as many as 129.2 million people (97.7\%).

\section{Content Knowledge (CK)}

Content Knowledge refers to subject matter knowledge that must be mastered when teaching (Kohler, et al, 2014; Schmidt \& Mishra, 2009), which in the context of this research is science material or content. Knowledge of material content includes various terms, theories, ideas, frameworks (Shulman, 1986). The results of the questionnaire data analysis on the Content Knowledge aspect are presented in Tables 2.1 and 2.2 below:

Table 2.1 Questionnaire results for aspects of Content Knowledge (CK) Social Studies

\begin{tabular}{|c|c|c|c|c|c|}
\hline No & Question & Rarely & Sometimes & Often & Always \\
\hline 1. & $\begin{array}{l}\text { I have sufficient knowledge about } \\
\text { social studies }\end{array}$ & & $1(10 \%)$ & $5(50 \%)$ & $4(40 \%)$ \\
\hline 2. & I can use historical thinking & & $1(10 \%)$ & $9(90 \%)$ & \\
\hline 3. & $\begin{array}{l}\text { I have a variety of ways and strategies to } \\
\text { develop my understanding of social } \\
\text { studies }\end{array}$ & & $1(10 \%)$ & $4(40 \%)$ & $5(50 \%)$ \\
\hline
\end{tabular}

Table 2.2 Questionnaire results for aspects of Content Knowledge (CK) Science

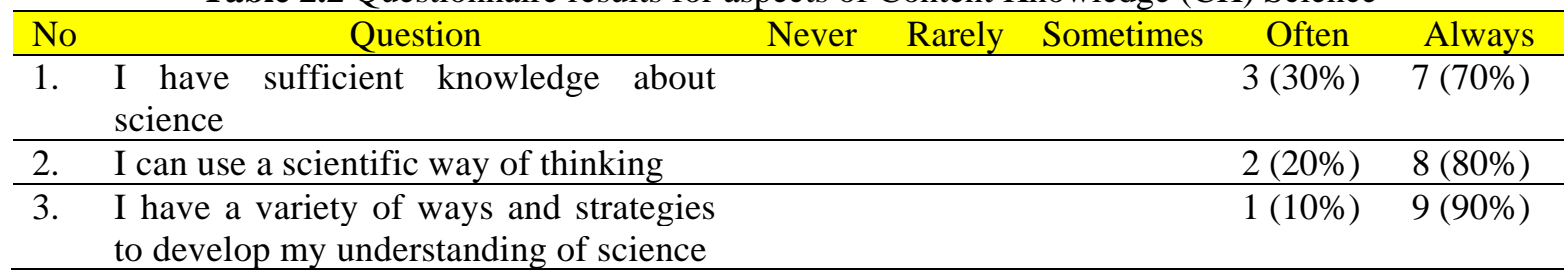

Based on the data table 2.1 the results of the questionnaire for aspects of Content Knowledge (CK) Social Studies can be explained and concluded that:

- The first question was about the teacher having sufficient knowledge about social studies, so the result was that 4 teachers answered always, 5 teachers answered often and 1 teacher answered sometimes. This shows that the average teacher has sufficient knowledge about social studies.

- The second question about teachers can use historical thinking, so the result is that 9 teachers answer often, 1 teacher answers sometimes. This shows that the average teacher often uses historical thinking.

- The third question regarding teachers has various ways and strategies to develop my understanding of social studies, so the result is

that 5 teachers answer always, 4 teachers answer often and 1 teacher answers sometimes. This shows that the average teacher has various ways and strategies to develop teachers' understanding of social studies.

Meanwhile, based on the data table 2.2 the results of the questionnaire for aspects of Content Knowledge (CK) Science can be explained and concluded that:

- The first question is about the teacher having sufficient knowledge about science, so the result is that 7 teachers answered always, 3 teachers answered often. This shows that the average teacher has sufficient knowledge 
about science.

- The second question is about teachers being able to use scientific thinking, so the result is that 8 teachers answer always, 2 teachers answer often. This shows that the average teacher always uses scientific thinking.

- The third question regarding teachers has various ways and strategies to develop my understanding of science, so the result is that 9 teachers answer always, 1 teacher answers often. This shows that the average teacher always has various ways and strategies to develop their understanding of science. This is in line with the research results of Hardinata A and Putri R E (2019) where the scientific literacy competence of teachers has above average results, even though they do not know what the definition of scientific literacy terminology is.

Tables 2.1 and 2.2 show that the aspects of content knowledge for junior high school teachers in the city of Medan are in the good category. Content knowledge is important for teachers to master (Mishra \& Koehler, 2008). If a teacher does not have a good knowledge of the content of the material to be taught, it can cause misconceptions and misrepresent facts (Koehler \& Mishra, 2009).

\section{Pedagogical Knowledge (PK)}

This aspect refers to knowledge of various teaching strategies and methods including knowledge of classroom management, learning assessment, and development of learning plans (Kohler, et al, 2014; Schmidt \& Mishra, 2009). The results of the questionnaire data analysis on the Pedagogical Knowledge aspect can be seen in Table 3 below:

Table 3. Questionnaire results for aspects of Pedagogical Knowledge (PK)

\begin{tabular}{|c|c|c|c|c|c|c|}
\hline No & Question & Never & Rarely & Sometimes & Often & Always \\
\hline 1. & $\begin{array}{l}\text { I know how to assess student performance } \\
\text { in a classroom }\end{array}$ & & & & $2(20 \%)$ & $8(80 \%)$ \\
\hline 2. & $\begin{array}{l}\text { I can adjust the way I teach based on the } \\
\text { understanding of the students }\end{array}$ & & & & $2(20 \%)$ & $8(80 \%)$ \\
\hline 3. & $\begin{array}{l}\text { I can adapt my teaching style in different } \\
\text { ways }\end{array}$ & & & $1(10 \%)$ & $4(40 \%)$ & $5(50 \%)$ \\
\hline 4. & I can assess students in many ways & & & & $1(10 \%)$ & $9(90 \%)$ \\
\hline & $\begin{array}{l}\text { I can assess student learning in many } \\
\text { ways }\end{array}$ & & & & $2(20 \%)$ & $8(80 \%)$ \\
\hline 6. & $\begin{array}{l}\text { I understand students' understandings and } \\
\text { misconceptions }\end{array}$ & & & & $2(20 \%)$ & $8(80 \%)$ \\
\hline 7. & $\begin{array}{l}\text { I know how to organize and maintain } \\
\text { classroom management }\end{array}$ & & & & $2(20 \%)$ & $8(80 \%)$ \\
\hline
\end{tabular}

Based on table 3 data, the results of the questionnaire for aspects of Pedagogical Knowledge (PK) can be explained and concluded that:

- The first question was about the teacher knowing how to assess student performance in the classroom, so the result was that 8 teachers answered always, 2 teachers answered often. This shows that the average teacher knows how to assess student performance in the classroom.

- The second question about the teacher can adjust the way I teach based on the students' understanding, so the result is that 8 teachers answer always, 2 teachers answer often. This shows that the average teacher can always adjust the way teacher teach based on the understanding of the students.

- The third question about the teacher can adjust my teaching style in different ways, so the result is that 5 teachers answered always, 4 teachers answered often and 1 sometimes. This shows that the average teacher can adapt their teaching style in different ways.

- The fourth question is about teachers being able to assess students in various ways, so the result is that 9 teachers answer always, 1 teacher answers often. This shows that the average teacher can always assess students in various ways.

- The fifth question is about teachers being able to assess student learning in various ways, so the result is that 8 teachers answer always, 2 teachers answer often. This shows that the 
average teacher can always assess student learning in various ways.

- The sixth question is about the teacher understanding students' understanding and misunderstanding, so the result is that 8 teachers answer always, 2 teachers answer often. This shows that the average teacher always understands students' understandings and misunderstandings.

- The seventh question is about the teacher knowing how to organize and maintain classroom management, so the result is that 8 teachers answer always, 2 teachers answer often. This shows that the average teacher always knows how to organize and maintain classroom management.

Table 3 above shows the Pedagogical Knowledge aspects of several junior high school teachers in the city of Medan who are in the good category. This means that the teacher has implemented pedagogical principles from planning, implementing, and assessing in classroom learning. Pedagogical knowledge is an important knowledge for teachers to master. As stated in UndangUndang No. 14 of 2005 on teachers and lecturers, one of the competencies that teachers and lecturers must have is pedagogical competence.

Pedagogical Content Knowledge (PCK) Pedagogical Content Knowledge (PCK) according to Shulman (1986) is an understanding of how certain topics or problems in a field of science are organized, represented, and adapted to the various interests and abilities of students, and implemented in the learning process. The results of the questionnaire data analysis on the Pedagogical Content Knowledge aspects can be seen in Table 4 below:

Table 4. The results of the questionnaire for aspects of Pedagogical Content Knowledge (PCK)

\begin{tabular}{|c|c|c|c|c|c|c|}
\hline No & Question & Never & Rarely & Sometimes & Often & Always \\
\hline & $\begin{array}{l}\text { I can choose an effective teaching } \\
\text { approach to guide students to think } \\
\text { and learn science, especially } \\
\text { temperature and heat materials }\end{array}$ & & & $1(10 \%)$ & $6(60 \%)$ & $3(30 \%)$ \\
\hline
\end{tabular}

Based on the data table 4 , the results of the questionnaire for aspects of Pedagogical Content Knowledge (PCK) can be explained and it can be concluded that:

- Questions about the teacher can choose an effective teaching approach to guide students to think and learn science, especially the material on temperature and heat, the result is that 3 teachers answer always, 6 teachers answer often and 1 teacher answers sometimes. This shows that the average teacher can often choose an effective teaching approach to guide students to think and learn science, especially temperature and heat material. With the ability of teachers to vary learning methods such as in the learning community Lesson study can also be used as a solution in instilling scientific abilities and attitudes in students.
This means that some junior high school teachers in the city of Medan are able and able to combine knowledge them about pedagogy and science of content/material/ temperature and heat in classroom learning. They know how to choose an approach to convey specific of content/science/temperature and heat content/materials in learning.

\section{Technological Content Knowledge (TCK)}

Technological Content Knowledge (TCK) is knowledge about the reciprocal relationship between technology and content (Kohler. et al, 2014), which in this case is science content. The results of the questionnaire data analysis on the Technological Content Knowledge aspects are presented in Table 5 below:

Tabel 5. Questionnaire results for aspects of Technological Content Knowledge (TCK)

\begin{tabular}{|c|c|c|c|c|c|}
\hline No & Question & Never & Sometimes & Often & Always \\
\hline 1. & $\begin{array}{l}\text { I know about technology that I can use to } \\
\text { understand and teach science, especially } \\
\text { temperature and heat materials }\end{array}$ & & & $7(70 \%)$ & $3(30 \%)$ \\
\hline 2. & I know to use technology that can be & & & $7(70 \%)$ & $3(30 \%)$ \\
\hline
\end{tabular}




\begin{tabular}{ll}
\hline & $\begin{array}{l}\text { used in understanding students to do } \\
\text { literacy }\end{array}$ \\
\hline 3. & $\begin{array}{l}\text { I know about technology that I can use to } \\
\text { help students understand and do science }\end{array}$ \\
\hline
\end{tabular}

Based on table 5 data, the results of the questionnaire for aspects of Technological Content Knowledge (TCK) can be explained and concluded that:

- The first question was about teachers knowing about the technology they could use in understanding and teaching science, especially temperature and heat, so the result was that 3 teachers answered always, 7 teachers answered often. This shows that the average teacher does not always know about the technology they can use in understanding and teaching science, especially temperature and heat material.

- The second question is about the teacher knows to use technology that can be used in understanding students to do literacy, so the result is that 3 teachers answer always, 7 teachers answer often. This shows that the average teacher knows how to use technology that can be used in understanding students to do literacy.

- The third question is about teachers knowing about the technology they can use in helping students understand and do science, so the result is that 4 teachers answer always, 5 teachers answer often and 1 teacher answers sometimes. This shows that the average teacher often knows about technology that

$1(10 \%) \quad 5(50 \%) \quad 4(40 \%)$

they can use in helping students understand and do science.

Table 5 above shows that the average Technological Content Knowledge aspects of some junior high school teachers in Medan are in good categories. This can be interpreted that the teacher knows and uses technology well in delivering material when learning takes place. As stated by Abbitt (2014) that TCK is a knowledge of how technology can influence and can be used in exploring scientific disciplines. Schmidt \& Mishra (2009) revealed that with TCK a teacher can change the way students understand and practice concepts in a scientific discipline.

\section{Technological Pedagogical Knowledge (TPK)}

Technological aspects of Pedagogical Knowledge (TPK) are knowledge of how various technologies can be used in teaching, understanding that using technology can change the way teachers teach (Schmidt \& Mishra, 2009). In other words, technology has an effect on the learning process (Abbitt, 2014). The results of the questionnaire data analysis on the Technological Pedagogical Knowledge aspects can be seen in Table 6 below:

Table 6. Questionnaire results for aspects of Technological Pedagogical Knowledge (TPK)

\begin{tabular}{|c|c|c|c|c|c|}
\hline No & Question & Rarely & Sometimes & Often & Always \\
\hline 1. & $\begin{array}{l}\text { I can choose technology that can improve } \\
\text { student learning for temperature and heat } \\
\text { science subjects }\end{array}$ & & & $5(50 \%)$ & $5(50 \%)$ \\
\hline & $\begin{array}{l}\text { I think critically about how to use } \\
\text { technology in my classroom }\end{array}$ & & & $3(30 \%)$ & $7(70 \%)$ \\
\hline
\end{tabular}

Based on the data table 6 , the results of the questionnaire for aspects of Technological Pedagogical Knowledge (TPK) can be explained and it can be concluded that:

- The first question is about the teacher being able to choose technology that can improve student learning for temperature and heat material science lessons, so the result is that 5 teachers answer always, 5 teachers answer often. This shows that the average teacher can choose technology that can improve student learning for temperature and heat science lessons.

- The second question is about teachers being able to think critically about how to use technology in the classroom, so the result is

that 7 teachers answer always, 3 teachers answer often. This shows that the average teacher always thinks critically about how to use technology in the classroom.

The data contained in the results of Table 6 shows that the aspects of Technological Pedagogical Knowledge (TPK) several junior high school teachers in the city 
of Medan are in good category. This is because the Technological Pedagogical Knowledge aspect requires technological means in educational institutions, technological completeness is facilitated so that the use of technology becomes effective in the process of learning temperature and heat.

When they choose a learning method/model they choose a learning method/model that uses little technology well, even though their knowledge of technology is high, they have difficulty integrating it with the pedagogical components used.
Technological Pedagogical and Content Knowledge (TPACK)

Technological Pedagogical and Content Knowledge (TPACK) is knowledge

about integrating technology into learning on specific or specific content (Schmidt \& Mishra, 2009; Kohler, et al, 2014). The results of the questionnaire data analysis on the Technological Pedagogical and Content Knowledge aspects can be seen in Table 7 below:

Table 7. Questionnaire results for aspects of Technological Pedagogical and

Content Knowledge (TPACK)

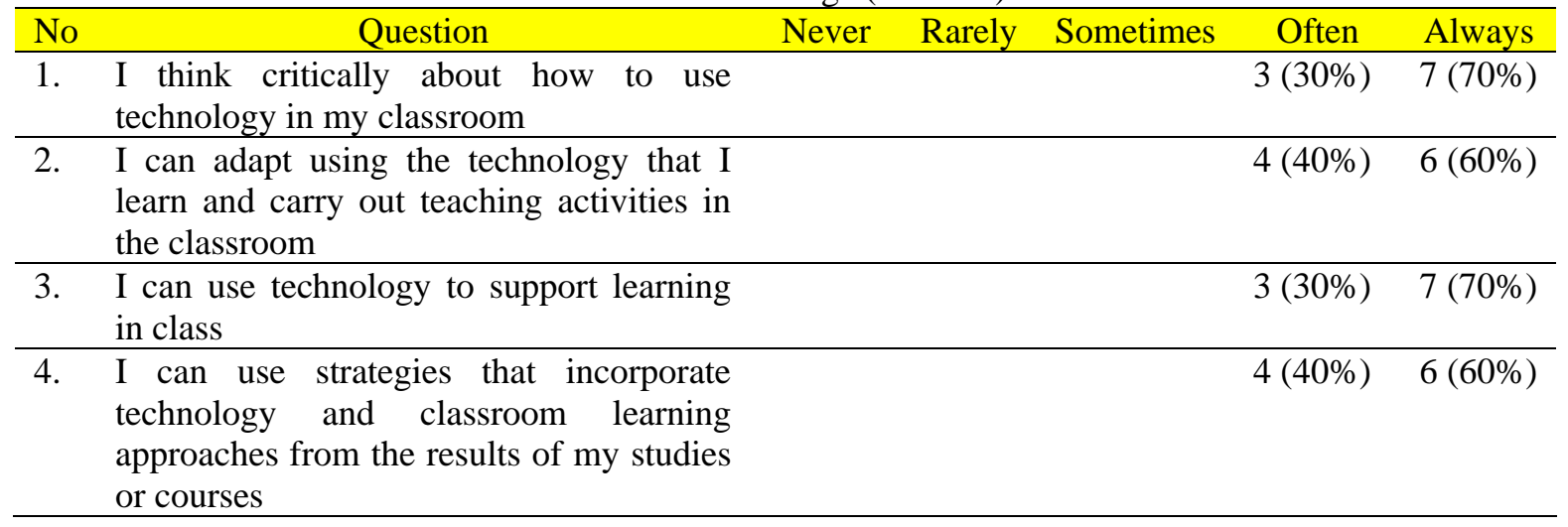

Based on the data table 7 , the results of the questionnaire for the aspects of Technology Pedagogy and Content Knowledge (TPACK) can be explained and it can be concluded that:

- The first question is about teachers being able to think critically about how to use technology in the classroom, so the result is that 7 teachers answer always, 3 teachers answer often. This shows that the average teacher always thinks critically about how to use technology in the classroom.

- The second question was about the teacher being able to adapt to the use of the technology I learned and carrying out teaching activities in the classroom, so the result was that 6 teachers answered always, 4 teachers answered often. This shows that the average teacher can always adapt to using the technology teacher have learned and carry out teaching activities in the classroom.

- The third question about teachers can use technology to support learning in the classroom, so the result is that 7 teachers answer always, 3 teachers answer often. This shows that the average teacher can use technology to support learning in class.

- The fourth question is that teachers can use a strategy that combines technology and learning approaches in the classroom from the results of the study or course, so the result is that 6 teachers answer always, 4 teachers answer often. This shows that the average teacher can always use a strategy that combines technology and approaches learning in the classroom from the results of studies or courses.

Based on the data in Table 7 above, it is revealed that the average value of the Technology Pedagogical and Content Knowledge aspects of some junior high school teachers in Medan is in the good category. It can be interpreted that the teacher is able to understand how to integrate technology knowledge, pedagogy and content/material in classroom learning.

\section{Conclusion}

Based on the instruments that have been developed, researchers have obtained that the teachers already know and apply TPACK in distance learning well through the understanding and abilities possessed by the 
junior high school science teachers in carrying out the learning process in the classroom, especially on the topic of temperature and heat.

\section{Reference}

Abbitt, J. T. 2014. An Investigation of the Relationship Between Self-Efficacy Beliefs About Technology Integrationand Technological Pedagogical Content Knowledge (TPACK) Among Preservice Teachers. Journal of Digital Learning in Teacher Education. 27(4), 134-143.

APJII. 2016. Saatnya Jadi Pokok Perhatian Pemerintah dan Industri. Buletin APJII Edisi 5.

Arikunto, S. 2010. Metode peneltian. Jakarta: Rineka Cipta.

Arina, U. R. 2018. Makna Metodologi Penelitian. Universitas Muhammadiyah Sidoarjo.

Chai, C.S., Koh, J. H.L., \& Tsai, C.C. 2013. A Review of Technological Pedagogical Content Knowledge. Educational Technology \& Society. 16(2). 31-51.

De Rossi, M. \& Trevisan, O. 2018. Technological Pedagogical Content Knowledge in the Literature: How TPCK is Defined and Implemented in Initial Teacher Education. Italian Journal of Educational Technology. 26(1): 8-23.

Denise A. Schmidt., et al. 2018. Survey of Preservice Teachers' Knowledge of Teaching and Technology. Jurnal Ekonomi dan Pendidikan. Vol. 8(1):1935.

Denise A. Schmidt, Evrim Baran, Ann D. Thompson, Matthew J. Koehler, Mishra, \& Tae Shin. (2018). JRTE: Survey of Preservice Teachers' Knowledge of Teaching and Technology. 42(2), 123149.

Departemen Pendidikan, I. P. A., and Jl Prof Dr Hamka. "Implementasi Literasi Sains Framework PISA 2015 melalui Lesson Study Dalam Pembelajaran IPA di SMP: Plan; Do; See." Jurnal SEMESTA 1.02 (2018): 12-18.

Drajati, Arifah, N. 2020. Pembelajaran bahasa Inggris dengan framework TPACK: kesempatan \& tantangan. Surakarta: Yuma Pressindo.

Hardinata, A., \& Putri, R. E. (2019). Implementation of scientific literacy competencies pisa framework 2015 through lesson study: teacher knowledge and result discussion. Journal of Physics: Conference Series, 1317, 012211

Hardinata, A., Simatupang, H., Hanifa, F., Latip, A., Efwinda, S., \& Yogica, R. (2020). SURVEY ON THE EFFECTIVENESS OF ONLINE LECTURES DURING COVID-19 PANDEMIC: METHODS AND DIFFICULTIES. Indonesian Science Education Research (ISER), 2(2), 7-12.

Hendriyani, E. M., Novi, R. 2020. Laporan Praktikum Mandiri Dalam Bentuk Video Presentasi Untuk Mengembangkan Kreativitas Dan Komunikasi Lisan Di Masa Pandemi Covid-19. Prosiding Seminar Nasional Pendidikan FKIP. 6(1): 2302-7827.

Koehler, M. J., Mishra, P., \& Cain, W. 2013. What Is Technological. Pedagogical Content Knowledge (TPACK)?. Michigan: Michigan State University.

Koehler, M. J., Mishra, P., Ackaoglu, M., \& Rosenberg, J. 2013. The Technological Pedagogical Content Knowledge Framework for Teachers and Teacher Educators. Commonwealth Educational Media Center for Asia.

Meili, Y \& Riandi. 2019. Analisis Technological Pedagogical Content Knowledge (TPACK) Guru Ipa Untuk Mengidentifikasi Profil Content Knowledge (CK) Guru Pada Materi Global Warming. Jurnal Wahana Pendidikan Fisika. 4(1), 37-41.

Mishra, P., \& Koehler, M. J. 2006. Technological Pedagogical Content Knowledge: A Framework For Integrating Technology In Teacher Knowledge. Teachers College Record. 108(6), 1017-1054.

Mulyana, D. 2008. Metodologi Penelitian Kualitatif. Bandung: Remaja Rosda Karya.

Orlando, J., \& Attard, C. 2015. Digital Natives Come of Age: The Reality of Today's Early Career Teachers Using Mobile Devices to Teach Mathematics. Mathematics Education Research. 28: 107-121.

Oyanagi, W. \& Satake, Y. 2016. Capacity Building in Technological Pedagogical Content Knowledge for Preservice Teacher. International Journal for Educational Media and Technology. 10 (1): 33-44. 
Pahlevi, R. M,. et al. 2021. Pelatihan TPACK (Technological, Pedagogical, Content Knowledge) Bagi Guru Bahasa Inggris di Kabupaten Karawang Jawa Barat. Jurnal Pengabdi. 4(1), 34-41.

Pinkley, D. 2010. Computer Technology in the Primary Classroom.

Rossisca, K., et al. 2019. Penerapan Metode Eksperimen pada Materi Kalor di Kelas VII SMP Negeri 2 Sengah Temila. Jurnal Pendidikan Sains dan Aplikasinya (JPSA). 2(1): 1-5.

Schmidt, D. A., Baran, E., Thompson, A. D., Mishra, P., Koehler, M. J., \& Shin, T. S. 2009. Technological Pedagogical Content Knowledge (TPACK): The Development and Validation of an Assessment Instrument for Pre-service Teachers. Journal of Research on Technology in Education. 42(2). 123149.

Shulman, L. S. 1986. Those Who Understand: Knowledge Growth in Teaching. Educational Researcher. 15(2): 4-14.

Sofyana \& Abdul. 2019. Pembelajaran Daring Kombinasi Berbasis Whatsapp Pada Kelas Karyawan Prodi Teknik Informatika Universitas PGRI Madiun. Jurnal Nasional Pendidikan Teknik Informatika. 8(1): 81-86.

Suryawati, E., Hernandez, Y. Firdaus L.N. 2014. Analisis Keterampilan Technological Pedagogical Content
Knowledge (TPCK) Guru Biologi SMA Negeri Kota Pekanbaru. Jurnal Biogenesis. 11(1), 67-72.

Swan, JKG. 2017. The Challenges of Online Learning: Supporting and Engaging the Isolated Learner. Journal of Learning Design. 10(1): 20-28.

Undang-Undang Nomor 14 tahun 2005 tentang guru dan dosen.

Witanecahya, S. Z. 2014. Penerapan Model Pembelajaran Inkuiri Terbimbing (Guided Inquiry) untuk Mengurangi Miskonsepsi Peserta didik Kelas X SMAN 2 Ponorogo pada Pokok Bahasan Perpindahan Panas. Jurnal Inovasi Pendidikan Fisika. 6-10.

Yulida, A. 2020. Analisis Kemampuan Technological Pedagogical Content Knowledge (TPACK) Pada Guru Matematika Dalam Penerapan Metode Discovery Learning di SMP Negeri Se Kec. Tuntang Kab. Semarang Tahun Pelajaran 2020. Salatiga: IAN Salatiga.

Zaitun., et al. 2020. Problematika Serta Strategi Penerapan Pembelajaran Jarak Jauh Berbasis Teknologi di Masa Pandemi Covid-19. Prosiding Seminar Nasional Penelitian LPPM UMJ. 1-8. 